\title{
Truthfulness in Religious Discourse
}

Hajj Muhammad Legenhausen

Complete truthfulness is rare in normal communication, let alone in discussions over sensitive topics like religion and politics. The situation is even worse if the conversation partners have different backgrounds and suspect that they will be misunderstood. Religious scriptures, however, seem to demand absolute truthfulness. In the Qur'ān, for example, it is written: "Do not mix the truth with falsehood, nor conceal the truth while you know. ${ }^{1}(2: 42)$ This is not merely a prohibition against lies and deceit, it is a demand for honesty of a very high caliber, and as such it is related to a number of philosophical discussions about truth and truthfulness, transparency, sincerity, deception, knowledge, and concealment. Furthermore, the context of this verse or $\bar{a} y a h$ (literally: sign; plural: $\bar{a} y \bar{a} t$ ) of the Qur'ān is one in which admonition is given to the "Children of Israel; « and, so, it also introduces the theme of intercommunal dialogue. In view of such considerations, reflections on this ayah will serve in what follows as an entry point to an Islamic view of topics related to truthfulness in interreligious dialogue.

\section{Arabic}

Before we can begin to consider any issues pertaining to truthfulness in the light of the Qur'ān, some linguistic remarks will be useful. Any discussion in which participants with scriptures in different languages are included must contend with fascinating linguistic subtleties and a recognition that translations are only approximations.

\footnotetext{
1 I am using the translation of Sayyid 'Ali Quli Qara'i, The Qur'an: With a Phraseby-Phrase English translation, Qom 2003, with modifications I consider to be helpful. Note that the word translated here as mix is talbisu, which literally means to dress, but is also used in the sense of mixing or confusing. So, one could understand the phrase to mean: "Do not disguise the truth with falsehood."This may seem somewhat ironic, since those who seek to deceive attempt to disguise their lies as truth, to dress up the false as though it were true, not to dress up the truth with falsity; but in Arabic usage the more literal meaning of the root is disregarded when the sense is mixing things up or adulteration.
} 
We have already seen a bit of this in the first footnote, with regard to the Arabic word talbisu for adulterating or mixing truth with falsity. More important than this are the terms used in the Qur'ān for truth itself, and truthfulness.

The most important of these words is حق (haqq). According to many exegetes its root meaning is that which is firm and stable. The word is related to the Hebrew חוק (hóqq, law), and in modern Arabic (and Persian), the plural, huquq is commonly used for rights. The Hebrew word's etymology has been traced to a meaning of being carved or engraved; and modern Arabic has the cognate hakkāk for lapidary. So, a reasonable conjecture is that there is a semantic shift from what is carved in stone, to permanent laws, to law and permanence, or, more generally, the right and the real, and, finally, divine reality. ${ }^{2}$

A common observation is that in the Qur'ān, haqq is used for both truth and what is real. ${ }^{3}$ If we consider haqq as that which is not adulterated with falsehood or deceptively garbed, a natural broadening of the meaning from a content to its bearer allows it to refer both to that which is uncovered and to that which uncovers or shows without deception. In this respect, it is worth comparing it to the Greek alethia, particularly with respect to some of the features of the concept discussed in the works of Martin Heidegger, who contrasted alethia $(\dot{\alpha} \lambda \dot{\eta} \vartheta \varepsilon \varepsilon \alpha)$ with the truth of correspondence theories due to its literal meaning without being hidden, from $\dot{\alpha}-$ (not) and $\lambda \dot{\eta} \vartheta \omega$ (I am hidden). Despite the literal meaning, Plato and Aristotle both used cognates of alethia for definitions of the truth and falsity of statements, and these definitions often have been interpreted as correspondence theories. In the Qur'ân, we find haqq used for that which is genuine and uncovered, as well as for the truth of statements and beliefs, and, additionally, for what is deserved (even if this is a punishment), and for what is practically correct.

Haqq is contrasted with what is false or vain bätil (باطل), ${ }^{4}$ or, less frequently, but no less importantly, with what is in error or astray

\footnotetext{
2 As explained in D. B. MacDonald/E. E. Caverley, Art. Haḳk, in: ${ }^{2}$ The Encyclopaedia of Islam,Vol. III, Leiden/London, 1986, 82-83.

3 See, for example: Massimo Campanini, Art. HAQQ / HAQIQA, in: The Qur'an: An Encyclopedia, ed. by Oliver Leaman, London and New York 2006, 247-249, here 247; Wilfred Cantwell Smith, Faith as Tașdīq., in: Islamic Philosophical Theology, ed. by Parviz Morewedge, Albany 1979, 96-119, here 101. Smith points out that there is a similar ambiguity between truth and reality in the words verum (Latin) and satyam (Sanskrit).

4 E.g., (8:8), (13:17), (17:81), (21:18), (31:30).
} 
daläl (ضلال). ${ }^{5}$ Allah guides with the truth, ${ }^{6}$ by the truth, ${ }^{7}$ and to the truth $;^{8}$ and He is al-Haqq. ${ }^{9}$ Al-Haqq is commonly said to be one of the ninety-nine beautiful names of God; and in Sufi theory, only God's existence is real; while all other existence is metaphorical. An exegetical question may be raised as to whether any of the occurrences of haqq in the Qur'ān for God specify the essence of God $(d h \bar{a} t)$ or are merely meant to affirm that God is truly the Lord, the Creator, He who raises the dead, etc. When the word is used for religion, din al-haqq,,$^{10}$ this can be understood to mean correct or true religion, one that guides to the truth, to true belief, true words, and true (or correct) action. Likewise, the Qur'ān is described as the truth ${ }^{11}$ because it guides to the truth and to a straight path $\aleph^{12}$. So, the question arises about the attribution of haqq to God. Does it mean that Allah is truly God, truly the Creator, the Lord, etc., or that He reveals the truth, and guides people to the truth and to the right way? One may hold that no more than this can be supported by the outward meaning of the text of the Qur'ann, and yet hold that in a deeper, but more speculative sense, God himself is the reality toward which He guides people through religion and revelation. ${ }^{13}$

One who rejects divine guidance, or denies or falsifies what has been revealed, goes astray and acts unjustly. ${ }^{14}$ One of the most condemnable ways in which the divine guidance is belied is to refuse to take it seriously, to take it as play $(l \bar{a} ' i b)$ or in vain and to mock it (huzu', from hazi'a). ${ }^{15}$ Those who are strongly condemned for doing this are not only those who rejected the revelation given to Muhammad, but those who had failed to take their own religion

\footnotetext{
5 E.g., (10:32), (42:18).

6 E.g., (32:3), (34:6).

7 E.g., (61:9).

8 E.g., (10:35).

9 E.g., (22:6), (18:44), (24:25).

${ }^{10}$ (9:44), (48:28), (61:9).

${ }^{11}$ (13:1), (23:62), (35:31).

12 (46:30).

${ }^{13}$ I am grateful to Ayatullah Misbah Yazdi for this point, made in conversation.

${ }^{14}$ E.g., (6:93), (29:68).

${ }^{15}$ See: (5:57-58). Significant parallels between the mocking of the āyat of the Qur'ān and the mocking of Christ in the Passion are drawn by Daniel Madigan, God's Word to the World: Jesus and the Qur'an, Incarnation and Recitation, in: "Godhead Here in hiding": Incarnation and the History of Human Suffering, ed. by Terrence Merrigan/Frederik Glorieux, Leuven, 2012, 157-172; cit. in Klaus von Stosch/Mouhanad Khorchide, Koranische Zugänge zu Jesus Christus in der Perspektive Komparativer Theologie, forthcoming in 2018.
} 
seriously. ${ }^{16}$ By contrast, God is said to have made heaven and earth not in vain, in jest $(l \bar{a}$ 'ibin $),{ }^{17}$ but in truth $\left(\right.$ bil-haqq) ${ }^{18}$

Without delving further into the interpretations of how the word haqq is used in the more than two hundred fifty àyāt of the Qur'ān in which it is mentioned, it should be clear that we are dealing with a very complex and rich polysemous term; and although it has been translated as truth (and reality) and has been used to translate alethia, it extends to considerations of rights and law in ways that are not matched by truth or alethia. Most striking is the idea of truth as a destination. Perhaps interreligious dialogues would profit if, instead of considering truth as a possession with regard to which conflicting claims are made, it were regarded as an aim.

When Aristotle's Metaphysics was translated into Arabic, haqq was used for alethia; but the translations of the logical works more often used șädiq or șidq for true ( $\dot{\alpha} \lambda \eta \vartheta \dot{\eta} \varsigma$ ), and occasionally șahīh (which is closer to correct, and is not found in the Qur'ān). ${ }^{19}$ The root $s d q$ is also the stem of words that appear in the Qur'ān with three main types of meaning, one related to truth (șidq, tașdīq, etc.), another associated with alms or charity (sadaqah, tașaddaqah, șaduqāt), and finally there are words meaning friend (sadīq). With regard to truth, it is used for words indicating sincerity, truthfulness, the truth of statements, confirmation of the truth of another person's statement, and for keeping promises and covenants. Truthfulness (sidq) is opposed to kidhb, from kadhaba, to lie against someone; and the early Muslim logicians most often used sidq and kidhb for true and false, respectively. ${ }^{20}$

Although the pairs haqq/battil and șidq/kidhb may often be used interchangeably, the former is more directly related to the quality of the content expressed in a belief or statement, while the latter is more centered on the person who holds the belief or makes the statement, or on the state of believing or act of affirmation.

\footnotetext{
${ }^{16}$ See: $(6: 70),(7: 51)$.

17 See: (21:16), (44:38).

18 E.g., (6:73), (14:19), (15:85), (16:3), (29:44).

19 These terms are compared in Smith 1979.

${ }^{20}$ Information about how Greek was translated into Arabic is available on the internet thanks to the invaluable work of those involved in the Glossarium Graco-Arabicum of the Berlin-Brandenburg Academy of Sciences and Humanities. See: http://telota. bbaw.de/glossga/ (20.12.2017).
} 


\section{Truth and Provocation}

Religious reform provokes controversy. Calls for reform are met by entrenchment and resistance. In some cases, the resistance might be justified. A false prophet or would-be reformer might trump up charges just to win a following. Muslims believe that the calls for reform in religious life that were issued by the true prophets were divinely authorized, and, hence, need to be taken seriously.

Relations between the religious communities that are heirs to movements for reform and the communities that see themselves in continuity with the earlier "unreformed institutions often retain mutual distrust and suspicion centuries later, no matter how clearly the original accusations do not apply to the contemporary denominations. The phenomenon is so widespread in all traditions that it is pointless to give more examples; further examples will surely come to the mind of the reader with little effort. Distrust and suspicion can make religious dialogue by members of these communities difficult and impede understanding when dialogue occurs.

In order to avoid provoking animosity, interfaith activists may refrain from saying anything that would cause dialogue partners to take a defensive position that could lead a discussion from a mutual quest for truth and understanding to a polemical battle of accusations and counter-charges. Interfaith meetings with participants who have not yet established a relation of trust often seem unable to engage in meaningful discussions that go beyond general expressions of good will and statements designed to show that they have some respect for the traditions of their dialogue partners. This can be especially frustrating for young activists who are eager to get to the "hard questions" and to hammer out consensus on contentious issues. To some observers and participants, many conferences and interfaith encounters might seem to be little more than BS sessions, ${ }^{21}$ a waste of time that produces little more than hot air.

If there really were nothing serious going on in interfaith discussions, there would be good reason to avoid them. The Qur'ān warns: "Leave alone those who take their religion for play and diversion and whom the life of this world has deceived « $(6: 70) .{ }^{22}$ On the other hand, it would be both a practical and a religious error to think that

\footnotetext{
${ }^{21}$ According to Harry G. Frankfurt, On Bullshit, Princeton, NJ 2005, the term bull session derives from bullshit session (also BS session), which is a discussion in which statements made do not necessarily reflect the considered beliefs of the speaker and need not express the sincere feelings of the speaker.

${ }^{22}$ Also see: (6:25), (22:3), (40:35).
} 
interfaith discussions must be confrontational to be serious: »Do not argue with the People of the Book except in a manner which is best, except such of them as are wrongdoers, and say, , We believe in what has been sent down to us and in what has been sent down to you; our God and your God is one [and the same], and to Him do we submit.« (29:46). ${ }^{23}$ To avoid making interfaith dialogue an idle mockery of serious discussion, we need to find a way out of the false dilemma that offers as exhaustive alternatives either an insistence on absolute and irreconcilable truth claims,${ }^{24}$ or a facile relativism that makes claims to religious truth arbitrary. To avoid both horns of the dilemma, we will consider how statements can be misleading even when what is said does not amount to outright intentional lying or insincerity. The a yah cited earlier gives a couple hints in this respect: "Do not mix the truth with falsehood, nor conceal the truth while you know." (2:42) The admonition gives examples of just two factors of a very general sort that can cause dialogue to fail-needless to say, there are other factors. Dialogue can fail when there is insufficient care about what is said, so that true and false are mixed and the aim of discussion is thwarted; and it can fail because of what is not said, because of what is concealed.

\section{Baloney}

In a popular essay first published in 1986, Harry Frankfurt gives an account of "bullshit" in which he draws on Max Black's remarks about "humbug«. Black defines humbug as »deceptive misrepresentation, short of lying, especially by pretentious word or deed, of somebody's own thoughts, feelings, or attitudes. $\aleph^{25}$ Bullshit, on the other hand, is characterized by Frankfurt by indifference to the truth. In a critical piece on Frankfurt's essay, Gerald Allan Cohen, also known as G.A. Cohen, offers an alternative understanding of bullshit as that which cannot be clarified, again falling short of lying. ${ }^{26}$ So, we can distinguish between Frankfurt-bullshit and Cohen-bullshit.

\footnotetext{
${ }^{23}$ Also see: (16:125).

${ }^{24}$ For more on this see Muhammad Legenhausen, Responding to the Religious Reasons of Others: Resonance and Nonreductive Religious Pluralism, in: European Journal for the Philosophy of Religion 5 (2013), 23-46.

${ }^{25}$ Max Black, The Prevalence of Humbug, Ithaca 1985, 143, cit. in Harry G. Frankfurt, On Bullshit, Princeton, NJ 2005.

${ }^{26}$ Gerald Allan Cohen, Deeper into Bullshit, in: Contours of Agency, ed. by Sarah Buss/Lee Overton, Cambridge, MA/London 2002, 321-339, here 332-334. For a more recent contribution and bibliography of relevant literature, see Andreas Stokke/
} 
Frankfurt-bullshit occurs when one does not take sufficient care that truth is not mixed with falsehood; Cohen-bullshit results from the concealment of the truth through obfuscation. To these, we can also add Stephen Colbert's truthiness, which, according to the analysis of Amber Griffioen, has two senses: believing on the basis of preference rather than evidence, truthiness; ${ }_{1}$ and believing on the basis of intuitions or "gut-feelings", truthiness ${ }_{2}{ }^{27}$ Here, I would like to step back to take a broader survey of the ways that statements can fall short of the religious demand for truthfulness without being outright lies.

Although interreligious dialogue may be marred by a certain amount of humbug, both kinds of truthiness, and both Frankfurtand Cohen-bullshit, what seems to be more prevalent, if no less pernicious, is what I would designate by the milder term: baloney. (This is a term of convenience; I am not claiming that the word baloney is commonly used in the manner I describe. Frankfurt and Cohen also both admit that ordinary language need not match the concepts they mean by the term bullshit.) The primary feature of baloney, in contrast to humbug, bullshit, and both kinds of truthiness, is that while these are all defined with regard to how they fail to provide reliable grounds for true belief, the failing of baloney is that it fails to provide appropriately relevant information to the issue at hand and so impedes understanding.

The intention to deceive is prominent in the discussions of Black, Frankfurt, and Cohen. Black builds the intention to deceive into the definition of "humbug«. Frankfurt and Cohen define their versions of bullshit in such a way that the one need not intend for one's audience to falsely believe what one has said is true for it to be bullshit. For Frankfurt, it will suffice if one is sufficiently negligent about whether what one says is true or not; and for Cohen, it will suffice if what one has said is sufficiently unclarifiable. However, Frankfurt does require an element of deception. Frankfurt-bullshitters deceptively convey the impression that they are concerned to communicate the truth..$^{28}$ Cohen is focused on the product rather than the intentions with which it is produced. Although lying depends on

\footnotetext{
Don Fallis, Bullshitting, Lying, and Indifference toward Truth, in: Ergo 4 (2017), 277309.

${ }^{27}$ Amber L. Griffioen, Irrationality and "Gut" Reasoning: Two Kinds of Truthiness, in:The Ultimate Daily Show and Philosophy, ed. by Jason Holt, Malden, MA/Oxford 2013, 209-325.

${ }^{28}$ We could also consider a version of bullshit in which the speaker does not intend to deceive the listener about what is said or about his concern for truth, and believes himself to be careful about getting things right, although the doxastic practice he employs is wildly unreliable. What he says might still be bullshit (contrary to Frankfurt),
} 
whether one intends to say what is false- and that distinguishes the lie from the honest mistake- one might allow that statements made without sufficient conscientious reflection about whether they are true might be the result of a willful disregard for the truth, but they might also result from unintentional oversight or just plain stupidity. So, there could be a variant of Frankfurt-bullshit that would not require the intention of bullshitters to deceive listeners about their own lack of regard for the truth. Likewise, statements of unclarifiable unclarity might be made on purpose to make the speaker seem profound, or they could result from rhetorical clumsiness. The Cohenbullshitter might deceptively attempt to convey the impression that what is being said is clarifiable despite knowing that it is not, or there may be no attempt to deceive at all. Closely related is the use of gobbledegook, difficult to understand jargon that ultimately may be clarifiable, but the clarification of which would take more time and patience than can be reasonably expected.

Similar remarks apply to truthiness and baloney: we should allow for intentional and unintentional varieties. The Qur'ān warns against trying to make truth conform to one's desires. ${ }^{29}$ Regarding truthiness, ${ }_{2}$, one might openly admit to relying on gut-feelings, or one may attempt to conceal the influence of intuitions in one's doxastic practices. The Qur'ān also condemns what might be considered truthiness ${ }_{2}$ as idle conjecture $(z a n n) .{ }^{30}$

The forms of inauspicious discourse that I am designating as $b a$ loney may also occur with or without deceptive intent. In this sense, speech may be a bunch of baloney not because it is false, not because its statements are unjustified, or are believed by the speaker for inappropriate reasons, and not because they are hopelessly unclear, but because they fail to shed light on the topic at issue. Baloney can be pointless drivel, but it can also be centered about a given topic in a coherent manner, as long as it serves to distract or derail the examination of the issue under discussion. Baloney is often trivial, self-serving, and uninformative; but none of these are essential. What is essential to baloney is that it is an obstacle to understanding the topic of discussion, and the hindrance is because of its being misleading- typically because of irrelevance.

even if by accident he does get things right, because it is improperly grounded. There is an indifference to truth, but an unintentional one.

29 "Had the truth followed their desires, the heavens and the earth would have surely fallen apart [along] with those who are in them. Indeed, We have brought them their Reminder, but they are disregardful of their Reminder." (23:71).

${ }^{30}$ "Most of them just follow conjecture; indeed conjecture is no substitute for the truth (haqq).«(10:36). 
Baloney need not reflect a disregard for truth. One can be quite scrupulous about making sure that everything one says is absolutely true, and yet one's speech could be a bunch of baloney. Lawyers and politicians seem to be very adept at this. The essence of baloney is that it is beside the point, that it does not contribute to understanding the issue at hand.

Baloney is related to understanding as bullshit is to truth. If one intends to evade an issue by making assertions that seem relevant but miss the point, we have deceitful baloney. The deceit might also involve convincing the audience that the speaker really is trying to answer the question that has been raised. General prime baloney is just off point, whether deceitfully or not. If one simply does not care about addressing the point at hand but steers the conversation in a direction to win some advantage, we have what might be called Frankfurt-baloney, since it is characterized by indifference to an epistemic goal. The goal pertaining to bullshit is truth of a proposition or set of propositions, while the pertinent goal to baloney is understanding an issue or topic.

Understanding a topic is not just the collection of a lot of truths about it; to have understanding one should have the know-how needed to explain how various aspects of the topic relate, and how the topic as a whole relates to other issues. ${ }^{31}$ While Frankfurt-bullshit is defined by indifference to the truth, Frankfurt-baloney is marked by indifference to the kind of appropriate relevance that enables one to understand an issue. If Cohen-bullshit is unclarifiable unclarity, we might distinguish a particular type of unclarity in which the meaning of what is said is clear enough, but its relation to the question under discussion is not, or there might be no way to clarify how what is said could serve any explanatory function with regard to the topic of discussion. This could be called Cohen-baloney. If truthiness 1 is the phenomenon of letting preferences determine belief instead of evidence, an analogue for understanding would be an incompetence that, because of preferences, is taken as having the relevant abilities. An analogue to gut-feeling truthiness, truthiness2, would be a kind of intuitive satisfaction with what one mistakes as one's expertise on an issue because one just feels that one is able to make illuminating explanations, despite the fact that one would be

31 This is controversial. Although understanding has been analyzed as a kind of knowhow by a number of writers, it is rejected by others. Here I merely assume that there is a kind of understanding a topic that is best seen as involving knowing-how. For a careful argument to the contrary and useful references to the literature, see Emily Sullivan, Understanding: not know-how, Philosophical Studies 175 (2018), 221-240. 
judged inept at navigating the space of reasons pertinent to the topic of discussion by those with greater expertise.

Once questions of baloney are raised, new analyses of some of the examples considered by Frankfurt and Cohen become possible. Although the two examples discussed below might seem to have little to do with interreligious dialogue, religious discourse often has features common to the examples when it is motivated by a desire to advertise one's own religious position and when it is designed to display a speaker's religious commitment or piety. Consider, for example, Frankfurt's discussion of the Marlboro cigarette company in his response to Cohen. Frankfurt thinks that the Marlboro company engages in deceptive advertising: "The cigarette company conveys in its advertisements the message that smoking Marlboros makes men as manly as cowboys. $\mathbb{1}^{32}$ The deception, however, is not intrinsic to its being bullshit, according to Frankfurt. It is bullshit because the company does not care whether the message is true or not; they just want to sell cigarettes. I think Frankfurt's focus on bullshit leads him to provide an incorrect analysis of what is wrong with the Marlboro ads. First, although I am not interested in defending the tobacco industry, the Marlboro company does not assert in its ads the message that smoking Marlboros will make anyone manly. If the company did, it could be sued for false advertising. Furthermore, if the ads did explicitly convey such a message, people would laugh at them. The psychology of the ads is more subtle. The ads stimulate a fantasy in which the manly cowboy and smoking Marlboros are associated. The company, in order to avoid lawsuits, might be very scrupulous about not making any false statements in their ads. So, the company and its advertising firm might not be indifferent at all to the truth. Frankfurt could respond that the attention to the truth is only at a superficial level. Indifference to the truth is found at the level of the hidden message. It would be very difficult, however, to show that there really is a hidden message that smoking makes one manly, as opposed to the hypothesis that the ads have no hidden message but seek to stimulate fantasies that will promote sales. The fantasy is designed in such a way as to make smoking seem attractive despite the known health risks, and despite the fact that the images of the cowboys are irrelevant to whether one should smoke. It is not carelessness about the truth that flaws the ads, as in Frankfurt-bullshit, but the diversion from what is important (health) to fantasies about riding the range. What is implicitly operative here is a fallacy of

${ }^{32}$ Harry G. Frankfurt, Reply to G. A. Cohen, in: Contours of Agency, ed. by Sarah Buss/Lee Overton, Cambridge, MA/London 2002, 340-344, here 341. 
relevance rather than disregard for truth (although there may well be disregard for truth, too). Smoking comes to be understood through the associated images of the fantasy rather than as an activity that is seriously detrimental to health.

Another example discussed by both Frankfurt and Cohen is a bombastic Fourth of July speaker. Frankfurt describes the speaker as motivated by a desire that his listeners think that he is a patriot, and the truth of what he says or what his audience comes to believe as a result of his praise of the founding fathers is a matter of indifference. As Cohen points out, the speaker might indeed be very careful to get his facts about the founding fathers right. If the speaker really does think of himself as a true patriot, and thinks that the speech is an effective way to get this true belief into the minds of his listeners, there need be no indifference to the truth at all. The problem with the speech and what makes it seem like so much hot air is that the strategy used to achieve the desired goal- the audience's belief in the patriotism of the speaker- is not justified by the content of the speech or the fact that it is presented. The desired conclusion is not relevant to whatever premises the audience could pick up from the presentation. The true patriotism of the speaker is not a good explanation for what is said in the speech. What is said in the speech can be considered baloney in relation to the aim of supporting belief in the speaker's patriotism.

Bombastic declamations designed to draw attention to the importance of the speaker are no more difficult to find on religious topics than political ones. While this kind of speech may include humbug, bullshit, and truthiness, all of which impede the aim of inquiry to find true answers to various related questions, it is the various kinds of baloney that are more pernicious, for without understanding, even if a truth is happened upon, it will have little value. Understanding is what enables one to make use of the truths one learns to make decisions, to develop theories, to explain things, and otherwise to apply what is learned in responses through action (whether linguistic or not), the expression of emotion, and cognition.

The informal fallacies listed in some elementary logic texts are also called fallacies of relevance. The employment of any of them, wittingly or not, can result in baloney. When one purposely answers a question by providing information designed to obscure what the speaker believes to be the truth of the matter, the speaker can be said to have used a smokescreen or to be guilty of the red herring fallacy. Even if the information given by the speaker is scrupulously 
true, it can hinder understanding by diverting attention from what is pertinent. ${ }^{33}$

Off-topic discussion, however, does not always impede understanding. It can do so; but often times off-topic discussions (in conference coffee breaks, for example) provide opportunities for the personal interchanges that can eventually lead to understanding an issue of discussion more effectively than formal presentations. Understanding can be blocked by emotional reactions to a religious tradition or even to a stance on some particular point of doctrine or practice. Finding common ground on matters that may not be directly relevant to a topic of religious discussion might alter the emotional relationship between the participants in such a way that they can more effectively come to understand one another.

\section{Religious Understanding}

In the Qur'ān, God seems to engage in some off-topic discussion with Moses. God asks Moses what he is holding. Moses answers: »He said, , It is my staff. I lean on it, and with it I beat down leaves for my sheep; and I have other uses for it." (20:18) What is the point of this exchange? God is not seriously asking His prophet for information, is He? The fact that the staff is used to beat down leaves for sheep seems to be completely irrelevant to the mission God gives Moses to confront the Pharaoh. A possible explanation for the exchange is that God seeks to open up communication with Moses, regardless of the value of the information. A relationship is sought. Lovers often say silly things to one another, not because they are bullshitting or violating some conversational norms, but because the exchange of words can have value independent of the truth and importance of its propositional content. Some conversations may be conducted just so that participants can become acquainted with one another, find out what they consider amusing, and develop some estimation of how they view things, generally. Building trust is only an elementary result of religious discussion that can be continued and deepened

\footnotetext{
${ }^{33}$ Andreas Stokke and Don Fallis consider some forms of evasion of a question under discussion (QUD) to be a form of bullshit with respect to that question. They do not consider evasion by purposefully stating what one believes to be true in a confusing manner. However, their focus on impediments to the advancement of a "subinquiry" defined with reference to a QUD is generally consistent with the account given here of baloney as that which hinders understanding. See Stokke/Fallis, Bullshitting, Lying, and Indifference toward Truth, 297-301.
} 
through friendship. By learning the kinds of cognitive and affective responses that can be expected from one's conversation partners, one becomes better able to steer the course of inquiry with them in ways that will be fruitful.

Outright deceit, humbug, bullshit, truthiness, and baloney can all be considered as impediments to the project of achieving mutual understanding, as well as the aims of individual participants to form only true beliefs pertinent to the discussion. The primary aim of interreligious dialogue should be mutual understanding, for in order to be able to judge whether the assertions of others are true, their positions first have to be understood. Inquiry generally does not aim at the mere accumulation of true beliefs; otherwise, one could easily amass uninteresting or trivial truths about any subject. ${ }^{34}$ This does not mean that absolute or exclusivist religious truth-claims must be abandoned or that a post-modernist rejection of the aim of truth is required..$^{35}$ One can understand a position without agreeing with it.

A particularly promising strategy for the promotion of religious understanding across denominational boundaries is comparative theology. By engaging in this discipline, conceptual abilities are developed through which understanding can be gained. ${ }^{36}$ Truthfulness then requires that we recognize that others may be justified in beliefs we do not share as well as in our common beliefs.

\section{Conclusion}

Interreligious dialogue, like any conversation, will have two aims concerned with furthering the project of mutual inquiry: ${ }^{37}$ finding the right answer to some question under discussion, and gaining mutual understanding of issues of concern. I have suggested that the goal of understanding should take priority. On many issues, religious differences are irreconcilable. Both in doctrine and in practice, there

\footnotetext{
${ }^{34}$ This has been pointed out by many authors. See, for example, Ernest Sosa, For the Love of Truth?, in:Virtue Epistemology, ed. by Abrol Fairweather/Linda Zagzebski, Oxford 2001, 49-62.

${ }^{35}$ One form that recognition of alternative religious positions can be understood is through the concept of ambiguity developed by Thomas Bauer. Although Bauer suggests that the post-modernist tradition may be helpful in this regard, he is also careful to steer clear of an empty relativism. See Thomas Bauer, Die Kultur der Ambiguität: Eine andere Geschichte des Islams, Berlin 2011, 114, 404.

${ }^{36}$ In this regard, the series Beiträge zur Komparativen Theologie, ed. by Klaus von Stosch, is exemplary.

${ }^{37}$ See Robert Stalnaker, Context, Oxford 2014.
} 
are differences that will not be solved simply by honest statements of position or appeals to available evidence. When understanding is increased and participants in dialogue discover aspects of faith in their dialogue partners with which they resonate, conflicts about contentious issues can be transformed due to the practical ability the participants find in navigating one another's perspectives.

- Muhammad Legenhausen is Professor of Philosophy at the Imam Khomeini Education and Reasearch institute, Qom, Iran. His research interests include philosophical theology, Islamic philosophy, comparative theology, and metaethics. 